\title{
Improving Learning Outcomes of Educational Research Methodology: Perceptions of the Assessment System, Learning Motivation and Emotional Intelligence among Indonesian Undergraduates
}

\author{
Enung Nugraha ${ }^{1}$, Maruf Akbar $^{2}$, S Supriyati $^{3}$ \\ (enungnugraha10@gmail.com ${ }^{1}$, maruf.akbar@unj.ac.id ${ }^{2}$, yetti.supriyati@unj.ac.id ${ }^{3}$ ) \\ Universitas Negeri Jakarta, Jakarta, Indonesia
}

\begin{abstract}
This research was conducted to describe students' perceptions of assessment system, learning motivation and emotional intelligence on learning outcomes of educational research methodology for students that completed educational research methodology courses in the Islamic State Universities of Banten, Indonesia. The random sampling method was used in selecting respondents for this study while path analysis with structural equation model (SEM) was used to analyze the hypotheses formulated. The results showed that all the indicators have direct effects on learning outcomes of educational research methodology; learning motivation directly affects emotional intelligence and learning outcomes, and that emotional intelligence directly affects learning outcomes. This shows that learning outcomes and students' opportunity can be improved for undergraduates undertaking the course in Indonesia.
\end{abstract}

Keywords: assessment system, learning motivation, emotional intelligence, learning outcomes.

\section{Introduction}

Educational research methodology is a strategic branch of science that discusses the methods used in research activities on limited lecture time. It involves students' perception of the behavior of lecturers, especially in assessing a subject study. On the other hand, learning motivation is a change of one's self-characterized energy marked by feelings and reactions towards goal achievement. Emotional intelligence is the ability to know and understand one's emotions and responsibilities as well as in relating with others effectively. Learning outcomes is the indicator of the achievement of learning objectives by students.

The above descriptions reveal that these attributes are interrelated and intertwined, therefore, it is important to research their relationships. Therefore, the aim of this research was to understand students' perceptions of the effect of the assessment system, learning motivation and emotional intelligence on learning outcomes in educational research methodology.

\section{Literature Study}


Krathwohl et al. (1964) argued that taxonomy consists of cognitive, affective and psychomotor domains. Cognitive include knowledge, understanding, application, analysis, synthesis, and evaluation. Affective include attitude, perspective, appreciation, emotion, and value while the psychomotor realm emphasizes some muscular or motor skills, manipulation of materials and things or similar action requiring neuromuscular coordination.

Katrien et al. (2005) pointed out that in the field of education, students are required to understand learning in accordance with reality so as to add value to themselves. This means that they do not only learn through various examinations and assessment used by their learning institutions but also through self-evaluation. Therefore, their perception of assessment has a significant influence on how they learn.

Hawkins et al. (2015) studied individual disciplining strategies in achieving learning outcomes and found that the use of interactions and motivations increase individual positiveness. Another research by Erin (2012) found that motivation predicts cumulative achievement index, thereby, revealing an indirect correlation between theories of intelligence and achievement. It shows that intelligence predicts learning outcomes and that a child's intelligence can be predicted from his or her parent's.

Learning outcomes are the attainment of a process through the stages memorization, comprehension, applicability, analysis, and evaluation which then result in the ability to have verbal information, intellectual skills, strategic cognitive attitudes, and physical or motoric skills. In order to achieve high learning outcomes, a lecturer is required to come up with a lesson that is always innovative, effective, efficient and attractive (Reigeluth,1983).

Lorin and David (2010) revealed that learners' participation in assessment procedures is important so that they can evaluate their own abilities, shortcomings, and errors and improve on them in order to meet the learning objectives. In another opinion, Judith et al. (2009) showed that when carrying out a task, physical term and assessment system are more authentic and aligned and that there is evidence of deeper learning and an increase in the general development of skills. Nevertheless, authenticity perceptions do not affect surface learning, therefore, more authentic assessment criteria decrease deep learning and generic skill development.

Appropriate assessment advances the energies, abilities, and beliefs of students. This can be objective, both in questions and judgments; comprehensive, assessing all aspects of student personality; effective and efficient by providing feedback, ensuring timeliness and supervision in evaluating the ability of learners. Jianpeng Guo (2018) revealed that this is supported by a model which showed that students' perceptions of the learning environment and prior academic achievement have direct effects on learning outcomes and indirect effects on their engagement.

Perception is the complex processing of the brain in order to personally organize and interpret an impression based on their appearance. This includes viewing, sounding, feelings, tasting and smelling so as to provide an adequate response, observation or comprehension. Therefore, students' perception of an appraisal system is their level of acceptance or interpretation of the assessment system.

Kenneth and Gary (1990) argued that motivation directly affects behavior because it is more involved in achieving goals. This has resulted in two motivational theories among students. The first is the theory of economic enterprise that explains the difference between the value held by teachers and students in each assigned task while the second is that of learner involvement that describes the motivational factors needed by teachers to create an exciting classroom environment (Simmons, 2014).

Emotional intelligence can be used to place emotions in the right portion, sort out satisfaction, and regulate the atmosphere. Robert and Ayman (1998) revealed that it explicitly enables hearts to activate one's deepest values and reflect them in an individual's living pattern. 
The heart is a source of energy and deep feeling which is needed to learn, create cooperation, lead and serve.

Kolachina (2014) revealed that there is a positive relationship between emotional intelligence and academic achievement among foreign students. It also showed that there are higher academic motivation achievement and a lower difference in emotional intelligence. Elizabeth and Richard (2014) in a study also found that the most influential step in the method of research is individual interaction. They further explained that emotional intelligence is driven by demographic issues of interaction and values that prevail in the environment.

Passing lecture methodology is compulsory for all students majoring in Islamic education faculty. The material used in the course is related to the theory and practice of educational research methodology. Khairul (2008) argued that the suitability of research methods depends on the nature of social phenomena to be explored. Basically, two basic traditional methodological research in social science are positivism and post-positivism (phenomenology).

\section{Methodology}

Survey method with path analysis and structural equation model (SEM) was used to analyze students' perceptions of the effect of the assessment system, learning motivation and emotional intelligence on learning outcomes for students of educational research methodology at the State Islamic Universities of Banten, Indonesia.

The instruments used include questionnaires with Likert scales and random sampling using Slovin formula. They were tested for validity, reliability, normality, regression, and linearity. Data were analyzed using descriptive statistics method and inferential statistics through standardization by confirmatory factor analysis as in Figure 1.

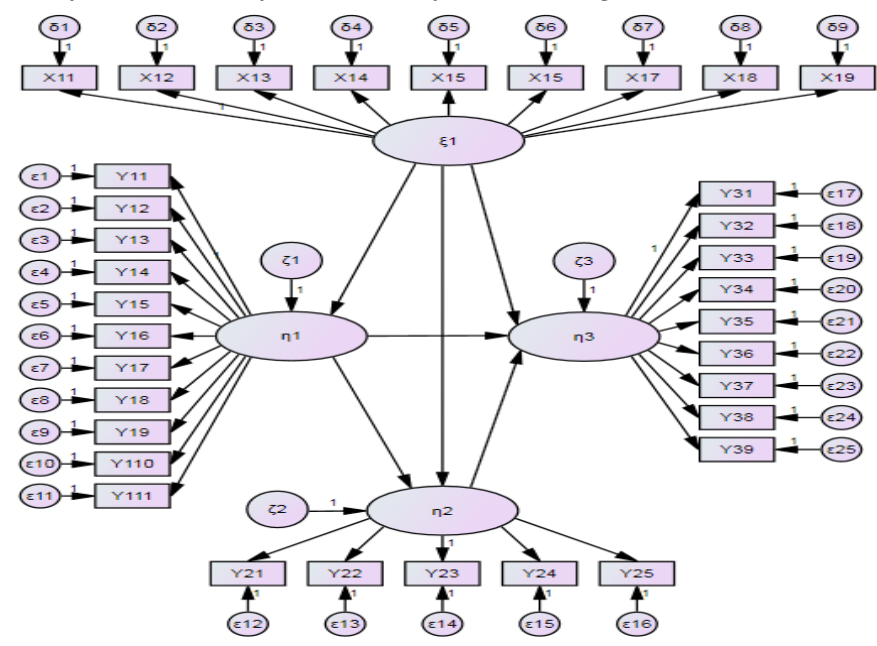

Fig.1. Constellation relationships between variables research

\section{Result}


Hypothesis analysis revealed that $\mathrm{P}$-value $<0,05$ for all the variables as shown in table 1 , therefore, all the hypotheses are rejected. This means that there is a direct relationship between the variables. The fit model was found to be good because it meets the necessary requirements (RMSI, GFI, AGFI, TLI, CMIN, CFI) as shown in figure 2.

Table 2. Results of research hypothesis testing

\begin{tabular}{|c|c|c|c|}
\hline Estimated error & Estimate & $\mathbf{P}$ & Note \\
\hline $\begin{array}{l}\text { Student perceptions of the assessment } \\
\text { system on student learning motivation }\end{array}$ & 0,15 & 0,040 & $\begin{array}{l}\text { Hypothesis } \\
\text { tested }\end{array}$ \\
\hline $\begin{array}{l}\text { Student perceptions of the assessment } \\
\text { system on emotional intelligence }\end{array}$ & 0,36 & $* * *$ & $\begin{array}{l}\text { Hypothesis } \\
\text { tested }\end{array}$ \\
\hline $\begin{array}{l}\text { Student perceptions of the assessment } \\
\text { system on learning outcomes of } \\
\text { educational research methodology }\end{array}$ & 0,10 & 0,046 & $\begin{array}{l}\text { Hypothesis } \\
\text { tested }\end{array}$ \\
\hline $\begin{array}{l}\text { Student learning motivation on } \\
\text { emotional intelligence }\end{array}$ & 0,48 & $* * *$ & $\begin{array}{l}\text { Hypothesis } \\
\text { tested }\end{array}$ \\
\hline $\begin{array}{l}\text { Motivation student learning on learning } \\
\text { outcomes of research education } \\
\text { methodology }\end{array}$ & 0,40 & $* * *$ & $\begin{array}{l}\text { Hypothesis } \\
\text { tested }\end{array}$ \\
\hline $\begin{array}{l}\text { Emotional intelligence on learning } \\
\text { outcomes of educational research } \\
\text { methodology }\end{array}$ & 0,43 & $* * *$ & $\begin{array}{l}\text { Hypothesis } \\
\text { tested }\end{array}$ \\
\hline
\end{tabular}

Note: $* * *$ showing $p$ value is very small $(<0,001)$

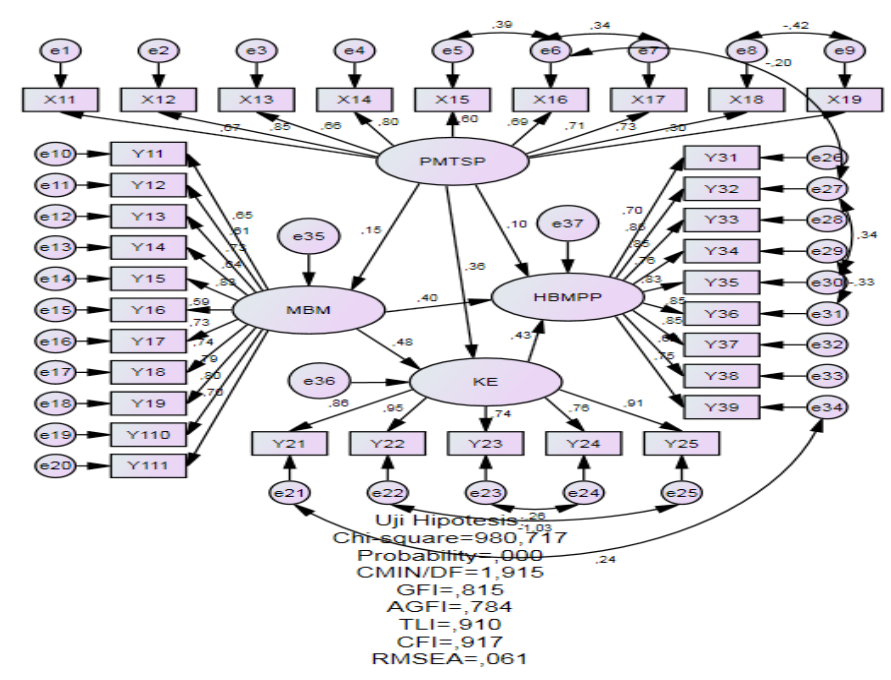

Fig. 2. Fit model of hypothesis testing

\section{Discussion}


Katrien et al. argued that students' perception of evaluation method also plays an important role because it makes them carry out assessment based on their perspective Then Judith et al. examined the relationship between perceptions of authenticity and alignment in learning and its outcomes and Jiangpeng Guo checked the relationship between student perceptions of the learning environment, previous academic achievement, involvement and learning outcomes.

The three studies above can be compared with the result of this research which shows that an evaluation system can be used to determine how to learn, live and add value in order to achieve better learning outcomes. The research with the largest sample is Jiangpeng Guo with 2616 respondents from one university while this study used 245 respondents from one study program at one university, however, the more the sample used, the better the contribution. This research made use of a lot of works of literature written between 1980-2002 (22 years) which were gathered from different internet sources. This study made use of the same correlational techniques as used in Jiangpeng and Judith but with the application of the structural equation model (SEM) using forty-two dimensions instead of the seventeen used by them. Katrien, on the other hand, made use of a qualitative method of research. However, the same result gotten from this research was also found in the three studies.

\section{Conclusion}

The research showed that students' perceptions of the assessment system, learning motivation and emotional intelligence have direct effects on learning outcomes of educational research methodology; motivation learning directly affects emotional intelligence and learning outcomes, and that emotional intelligence directly affects the learning outcomes of education research methodology.

\section{References}

[1]Krathwohl, D.R., Bloom, B.S., Masia, B.B. Taxonomy of educational objectives the classification of educational goals. Handbook II: Affective domain, pp. 134-138. David McKay Co.Inc Books, New York (1964)

[2]Struyven Katrien, F Dochy and S Janssens: Students perception about evaluation and assessment in higher education a review. Assessment \& Evaluation in Higher Education, Vol. 30, pp. 325-341. (2005)

[3]Hawkins, A. O., Rabenhorst-Bell, M. M. \& Hetzel-Riggin, M. D: Exploring racially diverse college students' perspectives on child discipline; a qualitative study, Journal Child Adol Trauma, Vol.8, pp. 7382. (2015)

[4]Erin Clevenger: Relation of a theory of intelligence to academic motivation and academic outcomes. doctoral dissertation, University of Florida (2012).

[5]Reigeluth, M Charles: Instructional-design theories and models, an overview of their current status. pp.89-96. New Jersey Books, London (1983).

[6]Lorin W. Anderson dan David R.Krathwohl (Editor): Kerangka landasan untuk pembelajaran, pengajaran, dan asesmen. pp. 42-45. Yogyakarta: Pustaka Belajar (2010).

[7]Judith T.M.Gulikers, Theo, J.Bastiaens, Paul A. Kirschner, and Liesbeth Kester: Relations between students perceptions of assessment authenticity and learning outcomes. pp.1 (2009)

[8]Jiangpeng Guo: Building bridges to student learning: Perceptions of the learning environment, engagement and learning outcomes among Chinese undergraduates. Studies in Educational Evaluation Volume 59, pp. 195-208 (2018)

[9]Kenneth N. Wexly and Gary A. Yukl: Organizational behavior and personnel psychology, pp.43-44. Richard D. Irwin Inc Books, San Francisco (1990) 
[10]Marc, Simmons: Students perceptions of motivation and impact on effort and performance: a grounded theory, study of affect and achievement motivation, doctoral dissertation. George Fox University (2014). [11]Robert K Cooper dan Ayman Sawaf: Executive EQ: kecerdasan emosi dalam kepemimpinan dan organisasi, pp. 64-68. Gramedia Pustaka Utama Books, Jakarta (1998).

[12]Kolachina, A: Impact of emotional intelligence on academic achievements of expatriate college students in Dubai. International Journal of Social Science and Humanities Research, 2 (2), pp. 9. (2014) [13]Elizabeth Ehrhardt Mustaine and Richard Tewksbury: Fathers methods of child discipline; does incarceration lead to hards and physical punished, A Research Note, pp. 89-99. (2014)

[14]Khairul B. M. Noor: A case studies a Strategic methodology universiti industri Selangor research, American Journal of Applied Sciences, Science Publications 5 (11), pp. 1602-1604 (2008). 